\title{
Comparative Pharmacognostical and Pharmacological Evaluation of two Achyranthes species
}

\author{
Pushpendra Kumar Shukla, Ankita Misra, Sharad Srivastava*
}

\section{Pushpendra Kumar Shukla, Ankita Misra, Sharad Srivastava*}

Pharmacognosy and Ethnopharmacology Division, CSIR-National Botanical Research Institute, Lucknow-226001, INDIA.

\section{Correspondence}

Sharad Srivastava

Pharmacognosy and Ethnopharmacology Division, CSIR-National Botanical Research Institute, Lucknow-226001, INDIA.

Phone No: 91-522-2297818

E mail Id: sharad_ks2003@yahoo.com

History

- Submission Date: 09-10-2017;

- Review completed: 20-11-2017;

- Accepted Date: 27-12-2017

DOI : 10.5530/pj.2018.2.54

Article Available online

http://www.phcogj.com/v10/i2

\section{Copyright}

(c) 2018 Phcog.Net. This is an openaccess article distributed under the terms of the Creative Commons Attribution 4.0 International license.

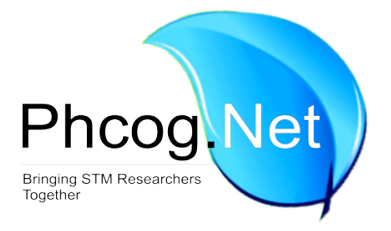

\begin{abstract}
Introduction: Achyranthes is a well-known herb used in folk lore and traditional systems of medicine for its therapeutic value. The two species Achyranthes aspera and Achyranthes bidentata are used interchangeably by people and by herbal industries due to their resemblance in appearance. Therefore, the present study was undertaken to evaluate the comparative pharmacognostic and pharmacological properties of both species. Methods: Pharmacognostic characters were evaluated as per the guidelines of Ayurvedic Pharmacopoeia of India. A quantitative HPTLC method was developed for quantification of linoleic acid and oleanolic acid using toluene: ethyl acetate: formic acid (6: $4: 0.5 \mathrm{v} / \mathrm{v} / \mathrm{v})$ as a mobile phase. Quantification was performed using linear regression analysis by plotting the peak area vs concentration curve with 2000-5000 $\mathrm{ng} / \mathrm{band}\left(\mathrm{R}^{2}=0.998\right)$ for oleanolic acid and $2000-5000 \mathrm{ng} / \mathrm{band}\left(\mathrm{R}^{2}=0.994\right)$ for linoleic acid. The developed method was validated in terms of accuracy, recovery and inter and intraday study as per ICH guidelines. Antioxidant activity of methanolic extracts was estimated by five different models viz. DPPH free radical scavenging assay, total anti-oxidant capacity, reducing power assay, total flavonoid and phenol content. Anti-diabetic activity was analyzed by $\alpha$-amylase inhibition assay using 3, 5 di nitro salicylic acid and iodine starch model. Results: The limit of detection (LOD) and limit of quantification (LOQ) of oleanolic acid and linoleic acid were determined, respectively, as $0.426,1.29$ and $0.427,1.29 \mu \mathrm{g} \mathrm{mL}-1$. Inhibition of free radicals increases with concentration and $\mathrm{IC}_{50}$ of $A$. aspera and $A$. bidendata was obtained at $1.35 \pm 0.173 \mathrm{mg} / \mathrm{ml}$ and $1.28 \pm 0.169 \mathrm{mg} / \mathrm{ml}$ respectively. In in vitro antidiabetic activity, $I C_{50}$ value shows that $A$. bidentata exhibit better activity than $A$. aspera. Conclusion: The present study generates data for the proper establishment of quality control standards of the crude drug.
\end{abstract}

Key words: Achyranthes, Antioxidant, $\alpha$ - amylase, HPTLC, Oleanolic acid, Linoleic acid.

\section{INTRODUCTION}

Achyranthes aspera L. (Amaranthaceae) is an erect herb found commonly as a weed throughout in India. In Ayurveda, it is used as abortifacient, treatment of fever, dysentery and diabetes. Various parts of species have potential pharmacological actions i.e. cardiovascular toxicity, pronounced insect malting hormonal activity, cure ophthalmia and opacities of cornea and are used as astringents, in abdominal tumors and stomach pain. ${ }^{1}$ Species also possess antibacterial, ${ }^{2}$ antiinflammatory ${ }^{3}$ and abortifacient activity, ${ }^{4}$ anti depressant, antinoniceptive and Hepato carcinogenic etc. ${ }^{5}$ It contains achyranthine an alkaloid, amino acids, carbohydrate, arhamnopyranosyl, B-D gluuronopyranosyl, B-D galactopyranosyl, sugars and inokosterone. ${ }^{6,7,8,9}$

Achyranthes bidentata Blume is also an erect, annual herb, grow in tropical and subtropical climatic regions of Asia The plant has been proven to have wide application in traditional and folk medicine in India, as well as other eastern countries. ${ }^{10}$ Traditionally, a paste of A. bidentata, Coix seed and Phellodendron amurense bark (In equal quantity), used on swollen part thrice a day. In Nepal, root is used for the tooth care. Medicinally, A. bidentata is used as anti-aging, ${ }^{11}$ antitumor, ${ }^{12}$ anti-senility, ${ }^{13}$ anti-inflammatory, anti-pyretic, antirheumatic, anti-inflamatoy, immunomodulatory and diuretic activity. ${ }^{14}$ The whole plant and particularly the root part have been shown to contain tyrosine, Rubrosterone, betaine, glycine, arginine, phytoecdysteroids, glutamic acid, various saponins, and polysaccharides. ${ }^{15,16,17,18,19}$ It is also very often sold in the market in place of $A$. aspera. ${ }^{20,21,22}$ The simultaneous quantification with method validation parameters of linoleic acid and oleanolic acid has not yet been reported in these species and therefore undertaken in this study which may be utilized for the proper standardization of these drugs.

\section{MATERIAL AND METHODS}

\section{Chemicals and reagents}

Ascorbic acid, quercetin, rutin, BHT (Butylated hydroxytoluene) and 1-1-diphenyl-2-pic-rylhydrazyl $(\mathrm{DPPH})$, were purchased from Sigma-Aldrich. All 
the solvents and chemicals (AR grade) are obtained from SD Fine Chemicals, Mumbai, India.

\section{Plant materials and preparation of extract}

Achyranthes aspera L. and Achyranthes bidendeta Blume were collected from Lucknow (U.P) and Palampur (H.P) respectively in the month of January- February. Specimen were authenticated and deposited in herbarium with voucher specimen numbers AS; 254035 and AB; 254034). Aerial parts were washed (water), shade dried and then powdered (40 mesh) for further analysis. $2 \mathrm{gm}$ powdered sample of each species was extracted successively in petroleum ether to remove the fatty impurity and then with methanol $(100 \mathrm{ml})$ for three times. Extracts were filtered, pooled, concentrated under standard conditions of temperature and pressure and then quantified.

\section{Phytochemical characterization}

Physicochemical parameters viz. Moisture content, total ash, water soluble ash, acid insoluble ash and extractive values (hexane, alcohol and watersoluble extractives) were evaluated and quantified. ${ }^{23}$ Various other metabolites i.e. sugar, starch, ${ }^{24}$ phenolics, ${ }^{25}$ flavonoids ${ }^{26}$ and tannin ${ }^{27}$ were also quantified as per standard protocols.

\section{In-vitro Antioxidant Activity}

Total phenolic content ${ }^{25}$ was calculated in terms of $\mathrm{mg} / \mathrm{gm}$ GAE (Gallic Acid Equivalent) based on calibration curve of Gallic acid as standard and total flavonoid contents ${ }^{26}$ of the extract was depicted in terms of $\mathrm{mg} / \mathrm{gm}$ of QE (Quercetin Equivalent). The anti oxidant potential was analyzed via ferric reducing power assay, ${ }^{28} \mathrm{DPPH}$ radical scavenging assay ${ }^{29}$ and total antioxidant activity etc. ${ }^{30}$

\section{In-vitro Anti diabetic (a-amylase inhibition) Activity Dinitro salicylic acid method (DNS)}

The inhibition assay was performed using standard DNS method. ${ }^{31}$ The results were expressed as \% inhibition calculated using the following formula:

$$
\begin{gathered}
\text { Inhibition activity }(\%)=\text { Abs }(\text { Control })-A b s(\text { extract }) \times 100 / \text { Abs } \\
(\text { Control })
\end{gathered}
$$

\section{Starch-iodine color assay}

Assay was carried out with slight modification based on the starch-iodine test. ${ }^{32}$ Inhibition of enzyme activity was calculated as:

$$
\text { Inhibition of enzyme activity }(\%)=(\mathrm{C}-\mathrm{S}) / \mathrm{C} \times 100
$$

where $\mathrm{S}$ is the absorbance of the sample and $\mathrm{C}$ is the absorbance of blank (no extract).

\section{Statistical Analysis}

Results were expressed as mean \pm S.D. Linear regressions analysis was carried out for standards to calculate total phenolic and flavonoid content and graph pad prism 5 software was used to calculate the $\mathrm{IC}_{50}$ values. One-way ANOVA followed by student's t test $(\mathrm{p}<0.01)$ was applied to find the significance in anti-oxidant and anti diabetic assay's.

\section{High Performance Thin Layer Chromatography Preparation of plant extract}

The coarsely powdered drug was completely extracted in methanol. The extract was filtered, dried and a stock solution of $10 \mathrm{mg} / \mathrm{ml}$ was prepared. The solution was filtered through a $0.45 \mu \mathrm{m}$ Millipore membrane filter (Pall, USA). A working solution of $1.0 \mathrm{mg} / \mathrm{ml}$ was prepared for HPTLC studies.

\section{Preparation of standard solution}

The stock solution of linoleic and oleanolic acid $(1 \mathrm{mg} / \mathrm{ml})$ was freshly prepared in methanol and was stored in the dark. The solutions were filtered through a $0.45 \mu \mathrm{m}$ Millipore membrane filter (Pall, USA) before application.

\section{HPTLC conditions}

For quantitative analysis, $10 \mu \mathrm{l}$ of the plant was applied on pre-coated plates with silica gel $60 \mathrm{~F}_{254}$ of $0.2 \mathrm{~mm}$ thickness as $6 \mathrm{~mm}$-wide bands positioned $10 \mathrm{~mm}$ from the bottom and $15 \mathrm{~mm}$ from side of the plate, using CAMAG LINOMAT V automated TLC applicator with nitrogen flow providing a delivery speed of $150 \mathrm{nl} / \mathrm{s}$ from application syringe. Following sample application, layers were developed in a CAMAG twin trough glass chamber which was pre-saturated with mobile phase Toluene: Ethyl acetate: formic acid (6:4:0.5 v/v). After development of the plate, it was dried and derivatized with Anisyldehyde sulphuric acid then scanned at $635 \mathrm{~nm}$ with a TLC scanner (WINCATS 1.3.2, CAMAG).

\section{Calibration curve of linoleic acid and oleanolic acid}

A stock solution of linoleic acid and oleanolic acid (1 mg mL-1) was prepared in methanol. Different volumes of stock solution were spotted on the TLC plate to obtain concentrations of 2000-5000 ng per band of linoleic acid and oleanolic acid respectively. The data of peak areas plotted against the corresponding concentrations were treated by least square regression analysis method validation.

\section{RESULTS AND DISCUSSION}

\section{Physico-chemical and phytochemical parameters}

Physicochemical and phytochemical parameters of both species were evaluated and represented in Figure 1 and Figure 2 respectively. A. aspera showed higher phenolic and flavonoid content than $A$. bidendeta Table 1.

\section{HPTLC Quantification of linoleic and oleanolic acid}

Quantification method of linoleic acid and oleanolic acid was developed and validated with mobile phase toluene: ethyl acetate: formic acid $(70: 2.5: 0.5, \mathrm{v} / \mathrm{v} / \mathrm{v})$ on precoated silica gel $60 \mathrm{~F}_{254}$ aluminum plates, and densitometric determination was carried out at $635 \mathrm{~nm}$. Linoleic and oleanolic acid as a marker were identified at $R_{f} 0.78 \pm 0.03$ and $0.89 \pm 0.02$ respectively. Quantification of linoleic and oleanolic acid was carried out on the basis of calibration curve of standards Table 4. Four dilutions of standards were used in concentration range of 2,3,4 and $5 \mu \mathrm{g} / \mathrm{ml}$ and various calibration values were obtained. Concentration of linoleic and oleanolic acid was found in A. aspera and A. bidendata is $0.018,0.016$ and $0.004018,0.011018 \%$ per dry weight respectively. (Figure 3, 4 \& 5)

\section{Method validation}

For the validation of the developed method, International Conference on Harmonization ( $\mathrm{ICH}$ ) guidelines was followed. Quantification was performed using linear regression analysis by plotting the peak area Vs concentration 2000-5000 ng/band (correlation coefficient: $r=0.999$, regression coefficient: $\mathrm{R}^{2}=0.998$ ) for oleanolic acid and 2000-5000 ng/band (correlation coefficient: $r=0.997$, regression coefficient: $R^{2}=0.994$ ) for linoleic acid.

Stock solutions of linoleic acid and oleanolic acid were prepared in four different dilutions and applied on HPTLC plate for preparing four-point linear calibration curves. The percentage content of analytes in the sample was calculated based on calibration curves Table 4 . To estimate the LOD and LOQ, the signal-to-noise ratio was determined. LOD was considered as 3:1 and LOQ as 10:1. LOD were obtained 0.427and $0.426 \mu \mathrm{g}$, whereas, the LOQ were found to be 1.29 and $20.12 \mu \mathrm{g} \mathrm{spot}^{-1}$ for compounds linoleic acid and oleanolic acid respectively Table 4. Precision validation of method was analyzed by interday and intraday 
repeatability studies at single level using fixed concentration $(1 \mathrm{mg} / \mathrm{ml})$ of standard solution. RSD (\%) values as shown in Table 6 are observed within the limit i.e. NMT 5\%. Accuracy is tested through standard addition method by spiking of samples at three different levels of 50, 100 and $150 \%$. Recovery of analyte Table 5 shows the variation from 100.02 to $100.06 \%$, which are in the acceptance limit of $95-105 \%$ and hence the method was found to be accurate and precise also. The validation results signify that the developed method is suitable for the quantitative analysis of linoleic acid and oleanolic acid compounds in Achyranthus species.

\section{In vitro antioxidant activity}

The antioxidant potential of the plant was further determined by the DPPH scavenging assay, ferric reducing power, and total antioxidant assay. The dose inhibition curve was used to determine the $\mathrm{IC}_{50}$ value, which is a quantitative measure used in determining the amount of sample required to show $50 \%$ inhibitory activity. The DPPH radical scavenging activity of methanol extract (aerial part) of both species effectively scavenged free radicals at different concentrations. Inhibition of free radicals increases with concentration and $\mathrm{IC}_{50}$ of $A$. aspera and A. bidendata was obtained at $1.35 \pm 0.173 \mathrm{mg} / \mathrm{ml}$ and $1.28 \pm 0.169 \mathrm{mg} / \mathrm{ml}$

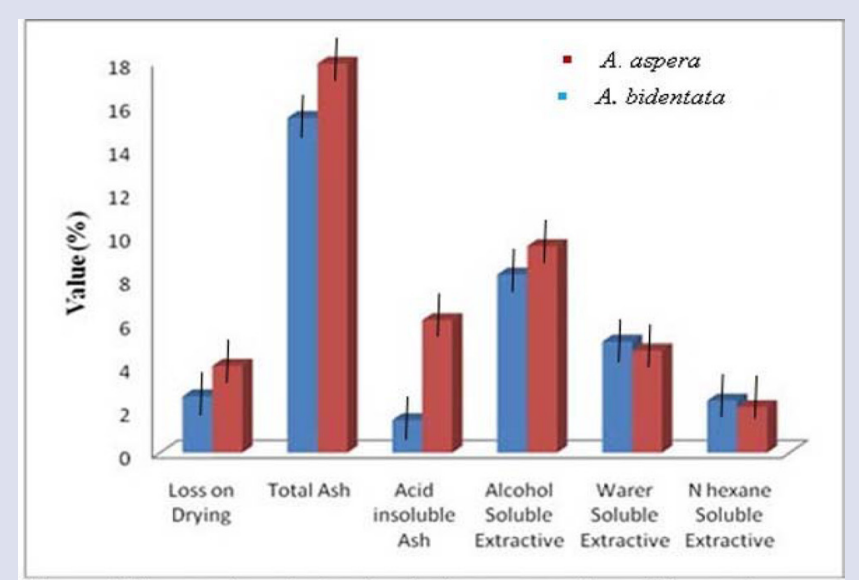

Figure 1 : Comparative physicochemical parameter of two Achyranthus species (Values are mean \pm S.D). respectively. Ascorbic acid, quercetin and rutin are used as a standard Table 2. Reductive capabilities of the methanol extract of the samples were studied in concentration range 25,50,100, 200 and $400 \mu l$ with Regression equation. $\mathrm{y}=0.0004 \mathrm{x}+0.4519\left(\mathrm{R}^{2}=0.9716\right)$ for $A$. aspera and $y=0.0004 x+0.4519\left(\mathrm{R}^{2}=0.9716\right)$ for the $A$. bidentata. The reducing ability was found to increase with concentration in both the samples. The total antioxidant capacity was also significance in both species with $\mathrm{y}=0.1593 \mathrm{x}+11.432,\left(\mathrm{R}^{2}=0.9791\right)$ in $A$. aspera and $\mathrm{y}=0.1271 \mathrm{x}+35.242$, $\left(\mathrm{R}^{2}=0.9712\right)$ in A. bidentata.

\section{Antidiabetic activity}

These species are also used in treatment of diabetes by local people therefore in the present study we have tried to validate these claims and it was found that both the species showed promising anti-diabetic activity Table 3. The methanolic extract of both the samples showed an increase in activity (inhibition of amylase enzyme) with the increase in concentration. $\mathrm{IC}_{50}$ shows that $A$. bidentata exhibit potential activity than $A$. aspera against both the tested models i.e. DNS and iodine-starch model. Acarbose, clinically used pancreatic amylase inhibitor exhibits the activity, ranges from $36.67-95.74 \%$ at concentration of $10-200 \mu \mathrm{g} / \mathrm{ml}$ respectively

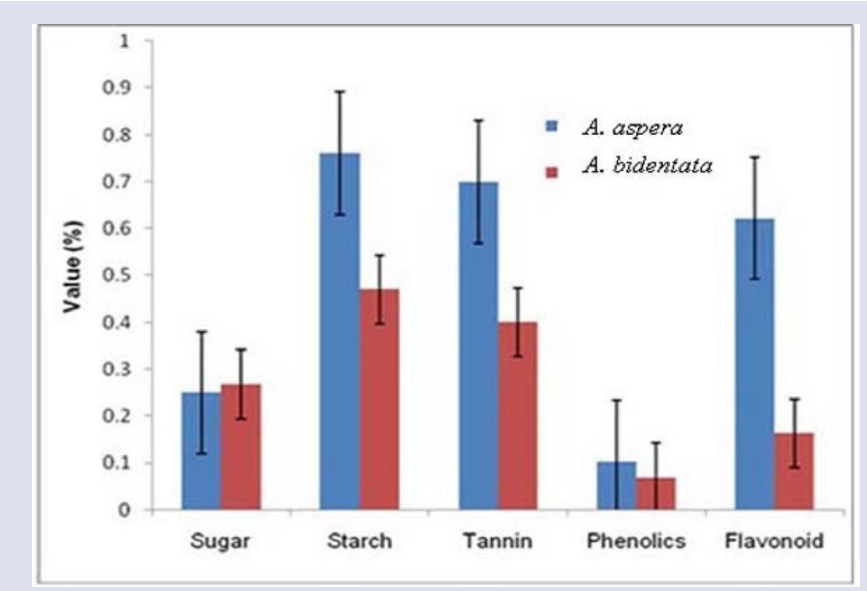

Figure 2: Comparative phytochemical parameters of two Achyranthus species (Values are mean \pm S.D).

Table 1: Estimation of total phenolics and flavonoids in A. aspera and A. bidentata aerial parts.

\begin{tabular}{ccc}
\hline Species & Total phenolic content $(\mathrm{mg} / \mathrm{g}) * \mathrm{GAE}$ & Total Flavonoid content $(\mathrm{mg} / \mathrm{g}){ }^{*} \mathrm{QE}$ \\
\cline { 2 - 3 } & $\mathrm{y}=146.2 \mathrm{x}-\mathbf{0 . 0 2 4}$ & $\mathrm{y}=81.37 \mathrm{x}-\mathbf{0 . 0 8 0}$ \\
$\mathrm{R}^{2}=\mathbf{0 . 9 9 8}$ & $\mathrm{R}^{2}=0.981$ \\
\hline A. aspera & $0.102 \pm 0.115$ & $0.622 \pm 0.119$ \\
A. bidentata & $0.069 \pm 0.115$ & $0.162 \pm 0.0113$ \\
\hline
\end{tabular}

${ }^{\star}$ Mean \pm S.D $(\mathrm{n}=3)$

Table 2: $\mathrm{IC}_{50}$ values of standard and Achyranthes species in DPPH radical scavenging activity.

\begin{tabular}{cc}
\hline Extracts & $\mathrm{IC}_{50}(\mu \mathrm{g} / \mathrm{ml})^{*}$ \\
\hline Ascorbic acid & $3.86 \pm 0.057$ \\
Quercetin & $5.93 \pm 0.115$ \\
Rutin & $6.8 \pm 0.173$ \\
A. aspera & $1.35 \pm 0.173 \mathrm{mg} / \mathrm{ml}$ \\
A. bidentata & $1.28 \pm 0.169 \mathrm{mg} / \mathrm{ml}$ \\
\hline
\end{tabular}

${ }^{*}$ Mean \pm S.D $(\mathrm{n}=3)$

Table 3: Comparative In-vitro anti-diabetic activity of $A$. aspera and $A$. bidentata (Aerial parts).

\begin{tabular}{ccc}
\hline Species & $\begin{array}{c}\text { a-amylase assay } \\
\mathrm{IC}_{50}(\mathrm{mg} / \mathrm{ml})^{*}\end{array}$ & $\begin{array}{c}\text { Starch-iodine assay } \\
\mathrm{IC}_{50}(\mathrm{mg} / \mathrm{ml})^{*}\end{array}$ \\
\hline A. aspera & $0.812 \pm 0.057$ & $0.027 \pm 0.057$ \\
A. bidentata & $1.005 \pm 0.048$ & $0.254 \pm 0.045$ \\
\hline
\end{tabular}

${ }^{\star}$ Mean \pm S.D $(n=3)$ 
Table 4: Calibration parameter of standards.

\begin{tabular}{ccc}
\hline Parameters & Oleanolic acid & Linolic acid \\
\hline Slop & 16255.0 & 10012.2 \\
Average & 14327.95 & 3546.96 \\
$\mathrm{R}_{\mathrm{f}}$ & 0.65 & 0.70 \\
Linearity range $(\mu \mathrm{g} / \mathrm{spot})$ & $2000-5000(\mathrm{ng} / \mathrm{mL})$ & $2000-5000(\mathrm{ng} / \mathrm{mL})$ \\
Regression equation & $\mathrm{y}=16255 \mathrm{x}+8638.7$ & $\mathrm{y}=10012 \mathrm{x}+42.68$ \\
Regression coefficient $\left(\mathrm{R}^{2)}\right.$ & 0.998 & 0.994 \\
Correlation coefficient $(\mathrm{r})$ & 0.999 & 0.997 \\
$\{(\mathrm{r})=\sqrt{ }(\mathrm{R} 2)\}$ & & \\
Standard deviation & 2100.15 & 1296.389 \\
Standard error & 101.586 & 121.794 \\
LOD $(\mu \mathrm{g} \mathrm{mL}-1)$ & 0.426 & 0.427 \\
LOQ $(\mu \mathrm{g} \mathrm{mL}-1)$ & 1.29 & 1.29 \\
\hline
\end{tabular}

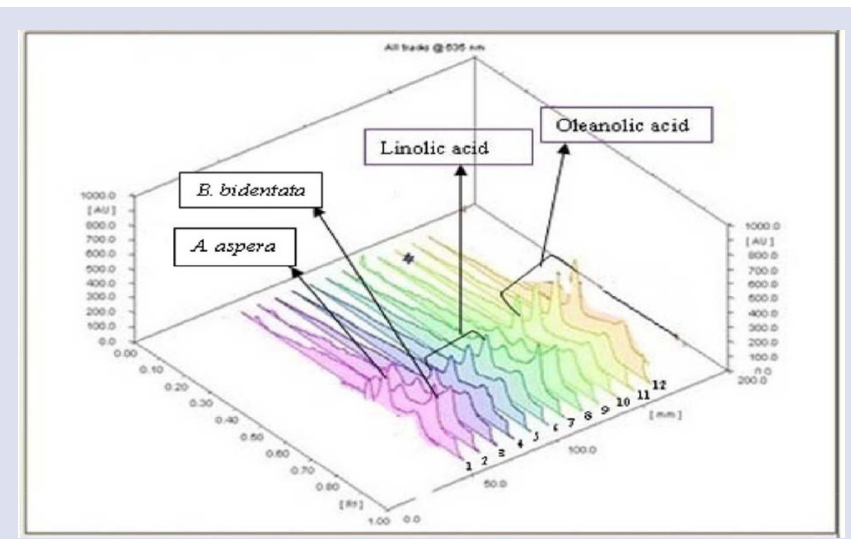

Figure 3: HPTLC 3D densitometric quantification of linolic acid and oleanolic acid in methanolic extract of $A$. aspera and B. bidentata Abbreviation: 1- Achyranthus aspera, 2-Achyranthus bidentata, 3 to6 Linolic acid, 7-Achyranthus aspera, 8- Achyranthus bidentata, 9 to 12 - Oleanolic acid.

Table: 5 Result and statistical data for recovery studies for linolic acid and oleanolic acid in A.aspera and A. bidendata.

\begin{tabular}{|c|c|c|c|c|c|c|c|c|c|c|c|c|c|c|c|c|}
\hline $\begin{array}{l}\frac{0}{0} \\
\text { हू } \\
\text { ज }\end{array}$ & 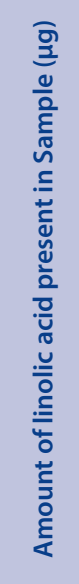 & 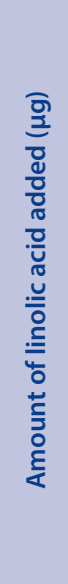 & 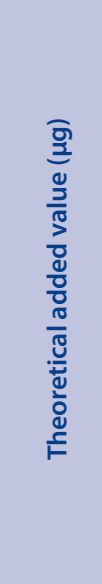 & 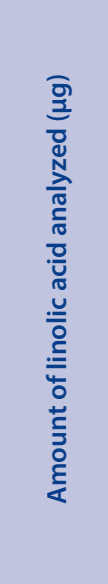 & 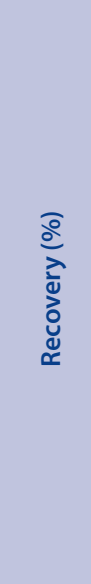 & 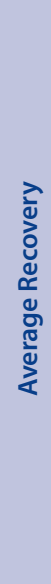 & คิ & ڤิ & 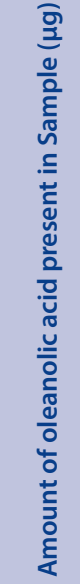 & 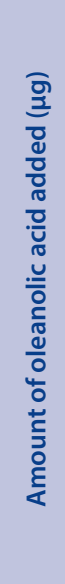 & 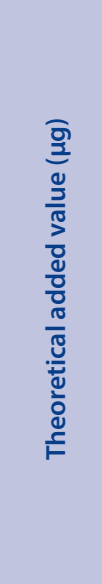 & 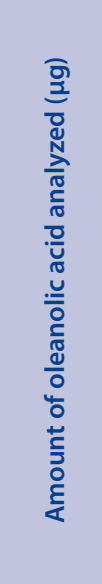 & 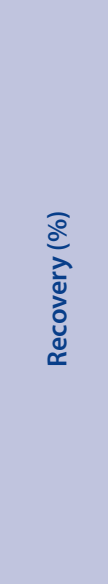 & 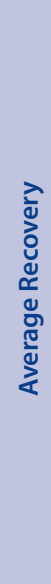 & ㅇ & ผิ \\
\hline \multirow{3}{*}{ A. aspera } & 0.018 & 50 & 50.018 & 50.021 & 100.01 & \multirow{3}{*}{$\begin{array}{l}\text { बे } \\
\text { बे }\end{array}$} & \multirow{3}{*}{0.011} & \multirow{3}{*}{0.011} & 0.004 & 50 & 50.004 & 50.005 & 100.001 & \multirow{3}{*}{$\begin{array}{l}8 \\
8 \\
8\end{array}$} & \multirow{3}{*}{0.0106} & \multirow{3}{*}{0.0106} \\
\hline & 0.018 & 100 & 100.018 & 100.017 & 99.99 & & & & 0.004 & 100 & 100.004 & 100.004 & 100 & & & \\
\hline & 0.018 & 150 & 150.018 & 150.016 & 99.99 & & & & 0.004 & 150 & 150.004 & 150.007 & 100.019 & & & \\
\hline \multirow{3}{*}{$\begin{array}{c}A . \\
\text { bidendata }\end{array}$} & 0.016 & 50 & 50.016 & 50.019 & 100.01 & \multirow{3}{*}{$\begin{array}{l}\text { बे } \\
\text { ूे }\end{array}$} & \multirow{3}{*}{0.011} & \multirow{3}{*}{0.015} & 0.011 & 50 & 50.011 & 50.012 & 100.001 & \multirow{3}{*}{$\begin{array}{l}\widetilde{\delta} \\
\text { ठ் }\end{array}$} & \multirow{3}{*}{0.0015} & \multirow{3}{*}{0.0015} \\
\hline & 0.016 & 100 & 100.016 & 100.012 & 99.99 & & & & 0.011 & 100 & 100.011 & 100.016 & 100.004 & & & \\
\hline & 0.016 & 150 & 150.016 & 150.17 & 99.99 & & & & 0.011 & 150 & 150.011 & 150.015 & 100.002 & & & \\
\hline
\end{tabular}

Table: 6 Precision studies for linolic acid and oleanolic acid.

\begin{tabular}{|c|c|c|c|c|c|c|c|c|}
\hline \multirow{3}{*}{$\begin{array}{l}\text { Concentration }\left(\text { ng spot }^{-1}\right) \\
\text { Amount of Standard }\end{array}$} & \multicolumn{4}{|c|}{ Linolic acid } & \multicolumn{4}{|c|}{ Oleanolic acid } \\
\hline & \multicolumn{2}{|c|}{ Intra Day } & \multicolumn{2}{|c|}{ Inter Day } & \multicolumn{2}{|c|}{ Intra Day } & \multicolumn{2}{|c|}{ Inter Day } \\
\hline & SD & $\%$ RSD & SD & $\%$ RSD & SD & $\%$ RSD & SD & $\%$ RSD \\
\hline 2000 & 10.81 & 0.371 & 18.24 & 0.741 & 21.407 & 0.179 & 13.07 & 0.105 \\
\hline 3000 & 20.67 & 0.512 & 16.45 & 0.443 & 21.669 & 0.161 & 20.78 & 0.151 \\
\hline 4000 & 23.60 & 0.464 & 21.29 & 0.396 & 11.385 & 0.076 & 12.26 & 0.076 \\
\hline 5000 & 12. 10 & 0.214 & 19.06 & 0.288 & 12.758 & 0.076 & 11.40 & 0.064 \\
\hline
\end{tabular}




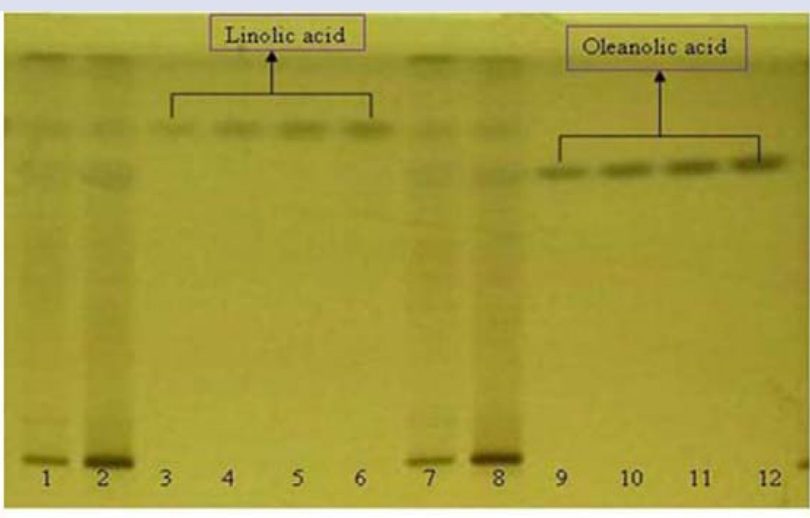

Figure 4: HPTLC finger prints of two Achyranthus species and standards at visible light Abbreviation: 1- Achyranthus aspera, 2-Achyranthus bidentata, 3 to 6 Linolic acid, 7-Achyranthus aspera, 8- Achyranthus bidentata, 9 to 12- Oleanolic acid.

Table 3. $\mathrm{IC}_{50}$ of Acarbose was observed at $32 \pm 0.01 \mu \mathrm{g} / \mathrm{ml}$. Study support the presence of effective in -vitro anti oxidant and anti diabetic activity in both the species. This can be very useful as the free radicals generated by body's innate mechanism/oxidative stress be one of the underlying cause of diabetes and hence, the synergistic action is appreciable.

\section{CONCLUSION}

For herbal drugs, TLC is an essential tool used in identification and quantification of chemical constituents. Oleanolic acid and linoleic acid was successfully quantified on normal phase silica gel HPTLC plates. The method was found to be reproducible and specific. Phytochemical estimation viz. total ash, acid insoluble ash, water soluble and alcohol soluble extractive value will be helpful in the identification, standardization and quality control of species. The antioxidant activity and anti-diabetic activity exhibited by Achyrenthes species suggests that there is little difference in their efficacy, therefore the two species can be used in herbal drugs.

\section{ACKNOWLEDGEMENT}

The authors are thankful to the Director of CSIR-NBRI for providing facilities and encouragement throughout the work.

\section{CONFLICT OF INTEREST}

There are no conflicts of interest.

\section{REFERENCES}

1. Srivastava S, Singh P, Mishra G, Jha KK, Khosa RL. Achyranthes aspera-An important medicinal plant: A review. J Nat Prod Plant Resources. 2011;1(1):1-14.

2. Aziz A, Rahman M, Mondal AK, Muslim T, Rahman A. Quader A. 3-Acetoxy-6benzoyloxyapagamide from Achyranthes aspera. Pharm J. 2005;4:1816-20.

3. Vetrichelvan T, Jegadeesan M. Effect of alcohol extract of Achyranthes aspera Linn. On acute and subacute inflammation. Phyto therapy Res. 2003;17(1):77-9.

4. Shibeshi W, Makonnen E, Zerihun L, Debella A. Effect of Achyranthes aspera L. on fetal abortion, uterine and pituitary weights, serum lipids and hormones. African Health Sci. 2006;6(2):108-12.

5. Kartik R, Rao ChV, Trivedi SP, Pushpangadan P, Reddy GD. Amelioration effects against $\mathrm{N}$-nitrosodiethylamine and $\mathrm{CCl}(4)$-induced hepatocarcinogenesis in Swiss albino rats by whole plant extract of Achyranthes aspera. Indian J Pharmacology. 2010;42(6):370-5.

6. Asolkar LV, Kakkar KK, Chakra OJ. Second supplement to glossary of Indian medicinal plants with active principles. Part I (A-K). Publication and Information Division, CSIR, New Delhi, India; 1992.

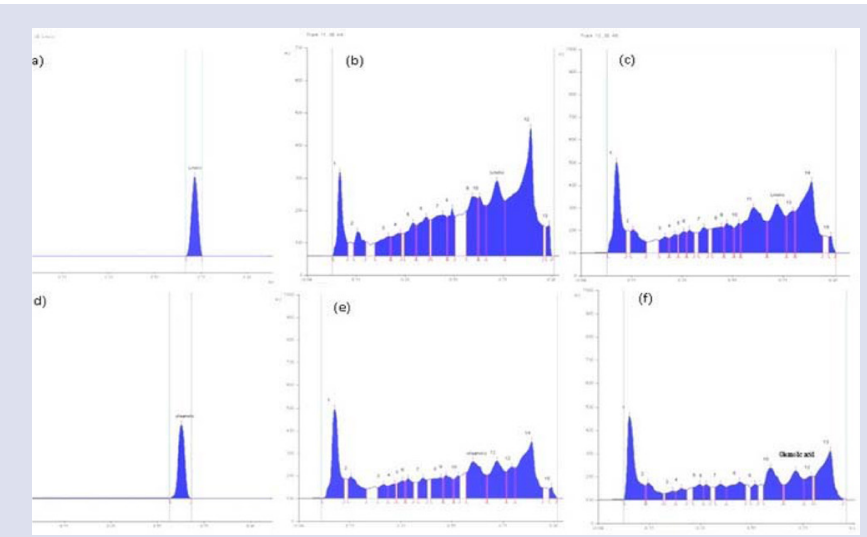

Figure 5: HPTLC chromatogram of (a). Linoleic acid (b), A. aspera (Ar.), (c) A. bidentata (Ar.), (d). Oleanolic acid, (e). A. aspera (Ar.), (f). A. bidentata (Ar.).
7. Rastogi RP, Mehrotra BN. Compendium of Indian Medicinal Plants, CDRI, Luknow and PID, New Delhi, India. 1993.pp.1-3.

8. Ghani A. Medicinal plant of Bangladesh with chemical constituents and uses, 2nd ed. Asiatic Society of Bangladesh, Dhaka. 2003.pp.71-2.

9. Qureshi R, Bhatti GR. Ethnobotanical observations of Achyranthes aspera Linn. And Aerva spp. with special reference to the people of Nara Desert. Hamdard Medicus. 2006;49(1):43-4

10. Lin, J. Zhang Z, Shan Y. Effect of Achyranthes bidendata polysaccharide on the expression of BCL-2 and bax in hepatic tissue after exhaustive exercise in rates. African J Tradition Complement. Alternative. Med. 2010;7(4):307-14.

11. Zhang ZY, Wang SK, Guo LK. Aging changes of neurotensin-like and dynorphinlike neurons in the central nucleus of amygdala of the rat anti-aging effect of radix Achyranthis bidentatae: Immunohistochemical and image quantitative analytical study. Chin J Anat. 1996;19(2):123-8.

12. Hu J, Qi YX, Li QX, Shan BE. The research of extract of Achyranthes bidentata Blume anti-tumor activity. Chin J Microbiology. Immunol. 2005;25(5):415-8.

13. Tan F, Deng J. Analysis of the constituents and antisenile function of Achyranthes bidentata polysaccharides. Acta Bot. Sin. 2001;44(7):795-8.

14. Yi S, Ken Y. New anti-inflammatory ergostane-type ecdysteroids from the sclerothium of Polyporus umbellatus. Biol. Med. Chem. Lett. 2008;18(11): 3417-20.

15. Wang $Q$, Yang $L$, Jiang $H$, Wang ZB, Yang BY, Kuang HX. Three new phytoecdysteroids containing a furan ring from the roots of Achyranthes bidentata $\mathrm{BI}$. Molecules. 2011;16(7):5989-97.

16. Yu B, Tian GY, Hui YZ. Structural study on a bioactive fructan from the root of Achytanthes bidentata BI. Chin J Chem. 1995;13:539-544

17. Marouf A, Hanquet B, Birlirakis N, Lacaille-Dubois MA. Two triterpene saponins from Achyranthes bidentata. Chem Pharm Bull. 2001;49(11):1492-4.

18. Li JX, Hareyama T, Tezuka Y, Zhang Y, Miyahara T, Kadota S. Five new oleanolic acid glycosides from Achyranthes bidentata with inhibitory activity on osteoclast formation. Planta Med. 2005;71(7):673-9.

19. Chen XM, XuYJ, Tian GY. Physical-chemical properties and structure elucidation of abPS isolated from the root of Achyranthes bidentata. Yao Xue Xue Bao 2005;40(1):32-5

20. Deng HB, Cui DP, Jiang JM, Feng YC, Cai NS, Li DD. Inhibiting effects of Achyranthes bidentata polysaccharide and Lycium barbarum polysaccharide on nonenzyme glycation in D-galactose induced mouse aging model. Biomed Environ Sci. 2003;16(3):267-75.

21. Li ZK, Li DD. The immunodulatory effect of Achyranthes bidentata polysaccharides. Yao Xue Xue Bao. 1997;32(12):881-7.

22. Xiang DB, Li XY. Effects of Achyranthes bidentata polysaccharides in interleukin-1 and tumor necrosis factor-alpha production from mouse peritoneal macrophages. Acta Pharmacologica. Sin. 1993;14(4):332-6.

23. Ministry of Health and Family welfare, Dept. of AYUSH. The Ayurvedic Pharmacopoeia of India. 2001;1(1):139-40

24. Folin O, Ciocalteu V. On tyrosine and tryptophane determination in proteins J. Biol. Chem. 1927:73(2):627-50.

25. El Far MM, Taie HA. "Antioxidant activities, total anthrocynins, phenolics and flavonoids contents of some sweet potato genotypes under stress of different concentrations of sucrose and sorbitol" Australian J Basic Applied Sc. 2009; 3(4):3609-16. 
26. Ghasemi K, Ghasemi Y, Ebrahimzadeh MA. Antioxidant activity, phenol and flavonoid contents of 13 Citrus species peels and tissues. Pak. J. Pharm. Sci. 2009; $22(3): 277-81$.

27. Oyaizu M. Studies on products of browning reactions: Antioxidative activities of products of browning reaction prepared from glucosamine. Japanese Japan Nutrition. 1986;44(6):307-15

28. Prieto P, Pineda M, Aguilar M. Spectrophotometric quantitation of antioxidant capacity through the formation of a phosphomolybdenum complex: specific application to the determination of vitamin E. Anal. Biochemistry. 1999;7:121-3.
29. Kim YM, Jeong YK, Wang MH, Lee YH, Rhee HI. Inhibitory effect of pine extract on alpha-glucosidase activity and postprandial hyperglycaemia. Nutrition. 2005; 21(6):756-61.

30. Sanchez-Moreno C, Larrauri JA, Saura-Calixto FA. Procedure to measure the anti radical efficiency of polyphenols. J. Sci. Food Agric. 1998;76(2):270-6.

31. Miller GL. Use of dinitrosalicylic acid reagent for determination of reducing sugar. Anal Chem. 1959;31(3):426-8.

32. Xiao Z, Storms R, Tsang A. A quantitative starch-iodine method for measuring alpha-amylase and glucoamylase activities. Anal. Biochemistry. 2006;351(1):146-8

\section{GRAPHICAL ABSTRACT}

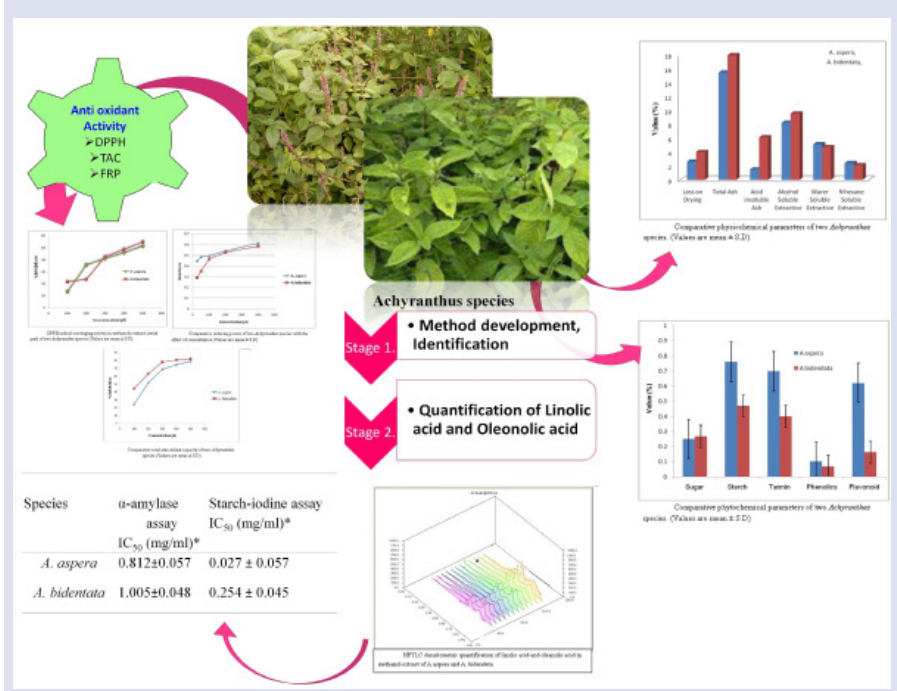

\section{SUMMARY}

- Physicochemical and phytochemical study was done to evaluate the quality standard of raw drug as per the guideline of API

- Maximum concentration of oleanolic acid was found in A. aspera; however, linolic acid was highest in A. bidendata

- In vitro antidiabetic activity, $A$. bidentata exhibit potential activity than $A$ aspera against both the tested models However; antioxidant capacity is almost similar in targeted species.

- The present study provides the scientific data for the proper authentication and establishment of quality standards for further.

\section{ABOUT AUTHORS}

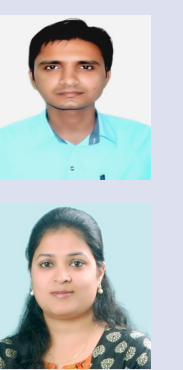

Pushpendra Kumar Shukla: Is working as RA in Pharmacognosy and Ethanopharmacology division, CSIRNational Botanical Research Institute, Lucknow, India. He is working in the area of analytical chemistry on medicinal plant, chemotaxonomy and handling of sophisticated instrument like AAS, HPLC, HPTLC, OPLC and UV spectrophotometer for identification, quantification of bioactive metabolites and standardization and quality control of herbal drugs.

Ms. Ankita Misra: Is working as a Research Associate in Pharmacognosy Division at CSIR-National Botanical Research Institute; Lucknow, INDIA. She is working in the area of analytical chemistry on medicinal plants, chemotaxonomy, bio-prospection and natural product development, handling major analytical instruments including HPLC, HPTLC, OPLC and column chromatography for quality control of herbal drugs. She has 18 publications in peer reviewed journals and 1 patent is also to her credit.

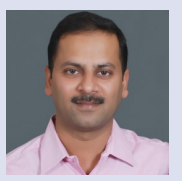

Dr. Sharad Srivastava: Is Principal Scientist in Pharmacognosy Division at CSIR-National Botanical Research Institute; Lucknow, INDIA. He has made significant contributions to quality control of crude drugs/products, chemotaxonomy, bio-prospection and natural product development and have developed quality parameters of single crude drugs (more than 70 medicinal plants) and also identified biomarkers for their quality control. He has contributed 30 monographs of single herbal drugs in Ayurvedic Pharmacopoeia of India. He has 115 publications in peer reviewed journals, 17 patents and developed some technologies/formulations, few has already been transferred to industry.

Cite this article: Shukla PK, Misra A, Srivastava S. Comparative Pharmacognostical and Pharmacological Evaluation of two Achyranthes species. Pharmacog J. 2018;10(2):309-14. 